\title{
Counselling skills in obstetrics and gynecological patients considering medical, emotional, cultural and legal perspectives: a commentary
}

\author{
Manika Agarwal, Kaushiki Singh*
}

Department of Obstetrics and Gynecology, NEIGRIHMS, Shillong, Meghalaya, India

Received: 08 December 2021

Revised: 16 January 2022

Accepted: 17 January 2022

\section{*Correspondence: \\ Dr. Kaushiki Singh, \\ E-mail: kaushikig8@gmail.com}

Copyright: $\odot$ the author(s), publisher and licensee Medip Academy. This is an open-access article distributed under the terms of the Creative Commons Attribution Non-Commercial License, which permits unrestricted non-commercial use, distribution, and reproduction in any medium, provided the original work is properly cited.

\section{INTRODUCTION}

Obstetrics and gynaecology is not only a field of medicine which deals with physical or mental disorders of the body. In some cases, while choosing the best option for a particular problem for a woman, consideration has to be given to existing cultural practices of the region and legal laws of the country, e.g. if the procedure being described is abortion by a lady, many factors will come into play before the decision is taken.

\section{REVIEW OF LITERATURE}

There have been several studies done to see the difference in results and outcome with positive and negative patient counselling.

In a systematic review done by Mannava et al, he found that a wide range of negative behavior of maternal health care provider (MHCP), affect the well-being and satisfaction of the patient in order to seek health care. They concluded that MHCPs need to pay more attention to the attitude and behaviour in order to improve the maternal health for the good of both the mother and the health care provider. $^{1}$

A randomised controlled trial was undertaken by Alder et al to determine whether the patient-physician communication in obstetrics and gynaecology can be improved by training and whether physicians who had poorer performance in the beginning showed greater improvement through the course of this study. The conclusion drawn was that there was only marginal improvement in the communication skills of the doctors with only partial satisfaction on patient side, but there was significant improvement in the performance of the physicians with poorer performance initially. He stated that communication training should be focused on improving the specific skill deficits rather than training the entire team of physicians. ${ }^{2}$

An article written by Fernando states that counselling is special communication skill and doctors with proficiency in this communication are likely to benefit by making accurate diagnosis, detecting any emotional disturbance in patients, satisfying the patients with their care and support and thus assuring patient compliance to the advice given. This is a way in which patient is helped to make better health care decisions. Therefore, counselling skills can prove to be valuable asset to doctors. ${ }^{3}$

\section{DISCUSSION}

We can elaborate on the above points by dwelling on different life situations which an obstetrician has to face quite frequently.

\section{Example 1}

A young unmarried girl of 17 years comes to obstetrics and gynaecology outpatient department (OPD) with her mother. Her presenting complaints are amenorrhea of 5 months. On evaluation, the obstetrician finds she is 5 months pregnant. The points to be considered by an obstetrician in an area and society where it is stigma for young unmarried girls to be pregnant would be the following. 


\section{Emotional aspect of mother}

Shock, disbelief, a feeling of family shame, anger towards girl and how to hide the news, how to proceed further, should an abortion be done, to hide or reveal this to the rest of the family, but to definitely hide from society.

\section{Emotional aspect of daughter}

Shame, sometimes guilt or sometimes self-righteousness and anger at family for not allowing her to live as she wants to as it is her private life and she has not done any harm to anyone.

\section{Emotional aspect of doctor}

How to break the news to patient and her mother and discuss options of MTP, under which clause, if it was result of consensual sex. In the present time, as per law, POCSO act, it is important to let the attendant know about the medicolegal formalities which need to be undertaken. Even though the family may want to hide issue, not undertaking medicolegal formalities may lead the doctors in problem in future.

Keeping the medical, cultural and legal perspectives in mind, the doctor has to break the news to patient and her attendant. Furthermore, the medical options of MTP have to be discussed in the backdrop of these cultural and legal frameworks.

\section{Example 2}

In case a young, unmarried girl has an ectopic pregnancy which needs surgical intervention or the girl can go into shock, the same issues have to be dealt urgently and tactfully. The doctor should be able to convince the parents to undertake lifesaving surgery immediately without thinking about other aspects as life is precious. Legal formalities have to be completed as a doctor may face dire consequences in future, if laws are not adhered to. If a woman is more than 18years but unmarried, the cultural perspectives remain the same though POCSO act is no longer tenable, so accordingly doctor may utilize his tact to counsel the patient.

\section{Example 3}

Even a young, unmarried girl, suffering from polycystic ovary syndrome (PCOS), hyperprolactinemia may present with amenorrhea. Advising such patients to get a urine pregnancy test done may be met with resistance. Some doctors get angry and tell the patients to do all investigations, as advised by them or they will not treat the patient, this should be avoided. Rather the doctor should understand the reason for their refusal, try to convince them for the need to do the test. In case patient still refuses, then document the refusal of the patient on the OPD card.

\section{Example 4}

Sometimes a doctor may come across a patient found to have human immunodeficiency virus (HIV) on investigations, requesting not to disclose to the husband her HIV status. The doctor needs to understand the ethical perspective and legal perspective of confidentiality and may refer the patient to a NACO center for further counselling.

\section{CONCLUSION}

There may be many such situations an obstetrician has to face where though the confidentiality is a right and request from the patient, but has to be weighed against legal and ethical aspects of hiding any relevant information from family or the legal authorities.

\section{REFERENCES}

1. Mannava P, Durrant K, Fisher J, Chersich M, Luchters S. Attitudes and behaviours of maternal health care providers in interactions with clients: a systematic review. Global Health. 2015;11:36.

2. Alder J, Christen R, Zemp E, Bitzer J. Communication skills training in obstetrics and gynaecology: whom should we train? A randomized controlled trial. Arch Gynecol Obstet. 2007;276(6):605-12.

3. Fernando SM. Communication skills and counselling. Sri Lanka J Obstet Gynaecol. 2012;34(2):69-71.

Cite this article as: Agarwal $\mathrm{M}$, Singh $\mathrm{K}$. Counselling skills in obstetrics and gynecological patients considering medical, emotional, cultural and legal perspectives: a commentary. Int J Reprod Contracept Obstet Gynecol 2022;11:655-6. 